\title{
SISTEM INFORMASI MANAJEMEN KEUANGAN DI PONDOK PESANTREN ADH-DHUHA
}

\author{
Reyhannisa Erico Dwi Ramadhana*1, Azizah Fatmawati*2 \\ ${ }^{1,2}$ Informatika, Universitas Muhammadiyah Surakarta \\ Email: ${ }^{1}$ ramreyhan@gmail.com, ${ }^{2} \underline{\text { af157@ums.ac.id }}$
}

(Naskah masuk: 19 Agustus 2020, diterima untuk diterbitkan: 28 September 2020 )

\begin{abstract}
Abstrak
Sistem informasi keuangan merupakan bagian penting dari sebuah instansi dalam melakukan manajemen keuangan. Beberapa instansi sudah memiliki sistem informasi keuangan sendiri namun tidak sedikit yang masih menggunakan sistem manual dengan menggunakan software Microsoft excel. Salah satu instansi yang masih menggunakan sistem manual yaitu pondok pesantren adh-dhuha. Penelitian ini bertujuan mengembangkan sistem informasi manajemen keuangan di pondok pesantren adh-dhuha. Sistem ini memiliki fitur pencatatan keuangan, mencari sekaligus mencetak laporan keuangan, dan mengolah permintaan laporan. Metode yang digunakan dalam penelitian ini yaitu waterfall terdiri dari analisis kebutuhan, desain, penulisan kode program, pengujian, penerapan. Sistem ini dibuat menggunakan bahasa pemrograman PHP dan Framework Codeigniter. Pengujian menggunakan System Usability Scale (SUS) dan Blackbox. Hasil pengujian blackbox testing menunjukan 100\% bahwa sistem sudah berjalan dengan baik dan setiap tombol sudah berjalan sesuai dengan fungsinya tanpa ada eror. Pada pengujian SUS dihasilkan nilai 74,25 sehingga sistem dinilai bekerja dengan baik dan layak untuk digunakan dalam melakukan manajemen keuangan yang baik.
\end{abstract}

Kata kunci: Keuangan, Sistem Informasi, Waterfall

\section{FINANCIAL MANAGEMENT INFORMATION SYSTEM IN ADH-DHUHA ISLAMIC BOARDING SCHOOL}

\begin{abstract}
Financial information systems are an important part of an agency in financial management. Some agencies already have their own financial information systems, but not a few still use manual systems using Microsoft Excel software. One of the agencies that still uses the manual system is the adh-dhuha Islamic boarding school. This study aims to develop a financial management information system in the adh-dhuha Islamic boarding school. This system features financial recording, search and print financial reports, and process report requests. The method used in this research, namely waterfall, consists of needs analysis, design, writing program code, testing, application. This system is built using the PHP programming language and the Codeigniter Framework. Testing using the System Usability Scale (SUS) and Blackbox. The blackbox testing results show $100 \%$ that the system is running properly and each button is running according to its function without any errors. In the SUS test, a value of 74.25 was generated so that the system was considered to be working well and was feasible to be used in good financial management.
\end{abstract}

Keywords: Finance, Information Sistem, Waterfall

\section{PENDAHULUAN}

Pondok Pesantren Adh-Dhuha melakukan pengolahan data keuangan masih menggunakan sistem manual. Pencatatan uang masuk atau keluar masih menggunakan Software Microsoft excel sedangkan data yang harus diolah tidak sedikit. Hal ini dinilai dapat menimbulkan masalah pada laporan keuangan, seperti kesalahan memasukan data keuangan sehingga hasil dari laporan tidak sesuai dengan kondisi yang ada [1]. Pengolahan data keuangan dengan sistem manual juga membuat pengguna mengalami kesulitan ketika proses memasukan rumus saat melakukan perhitungan dan pengguna harus bekerja lebih teliti karena data yang dimasukan sangat banyak [2].

Sistem informasi keuangan menjadi salah satu solusi untuk sistem lama yang dinilai masih memiliki beberapa kekurangan. Penggunaan sistem informasi keuangan ini dapat membantu pengguna dalam melakukan manajemen keuangan dan menghasilkan laporan dengan baik. Laporan menjadi sumber informasi penting sebuah instansi dalam menentukan 
rencana dan langkah kedepan agar tujuan dari instansi tersebut dapat terlaksana [3]. Dalam pembuatan laporan keuangan, sistem dapat mengolah data secara cepat dan akurat. Sistem juga dapat membantu pengolahan data yang dimasukan oleh pengguna secara otomatis sehingga kesalahan pengolahan data oleh pengguna dapat diminimalisir [4].

Secara singkat sistem informasi keuangan membuat pekerjaan lebih efektif dan membuat pengguna nyaman dalam berkerja. Tata kelola dalam sistem manajemen keuangan juga berpengaruh terhadap kualitas laporan keuangan yang dihasilkan, semakin baik tata kelola yang dijalankan maka semakin sedikit kesalahan dalam laporan keuangan [5]. Laporan keuangan yang dibuat harus sesuai dengan kebutuhan sehingga laporan dapat digunakan oleh pihak yang membutuhkan. Salah satu aspek yang juga berperan penting dalam menghasilkan laporan keuangan yang baik adalah perilaku pengguna yang bertanggungjawab [6]. Dengan adanya sistem manajemen keuangan yang baik akan menunjang kemajuan instansi serta dapat membantu terbentuknya manajemen keuangan yang lebih baik [7].

Sistem yang akan dikembangkan membutuhkan beberapa alat bantu untuk pengembangan sistem yaitu PHP, MySQL, dan XAMPP. PHP digunakan karena programmer dapat merancang halaman web secara dinamik serta bersifat open source sehingga setiap orang dapat menggunakan secara gratis. MySQL mendukung programmer untuk pengolahan data dari menyimpan, mencari, menerima, dan menyusun di sebuah database. Mengembangkan sistem berbasis web menggunakan PHP maka diperlukan juga server dan interpreter PHP dengan cara menginstal XAMPP. Dengan adanya alat bantu maka dalam melakukan pengembangan sistem dapat berjalan dengan maksimal dan baik [8].

Penelitian yang dilakukan ini memiliki kelebihan dari hasil penelitian terdahulu. Kelebihan dari sistem informasi keuangan saat ini terdapat fitur permintaan laporan yang harus dicetak pada tanggal tertentu. Fitur permintaan laporan ini didasarkan pada data yang diminta oleh pihak terkait. Dengan ditambahnya fitur ini diharapkan memudahkan pengguna dalam melakukan manajemen keuangan. Sistem informasi keuangan ini nanti akan dikembangkan dengan beberapa fitur pada umumnya seperti pencatatan pemasukan dan pengeluaran, mencetak laporan, mencari data, dan melihat saldo yang ada

\section{METODE PENELITIAN}

SDLC (System Development Life Cycle) adalah proses mengembangkan atau mengubah suatu sistem perangkat lunak dengan menggunakan model-model dan metodologi yang digunakan orang untuk mengembangkan sistem perangkat lunak sebelumnya [9]. SDLC memiliki beberapa model yang dapat digunakan, salah satunya model waterfall.
Metode pada penelitian ini yaitu menggunakan metode waterfall. Metode waterfall sering digunakan oleh peneliti pada umumnya karena dalam pelaksanaan penelitian dilakukan secara sederhana dan urut sehingga jika ada langkah yang belum selesai maka tidak bisa melanjutkan ke langkah selanjutnya. Langkah-langkah dari metode waterfall yaitu Analisis kebutuhan, Desain, Penulisan kode program, Pengujian, Penerapan [10]. Pada gambar 1 menampilkan gambar dari metode waterfall.

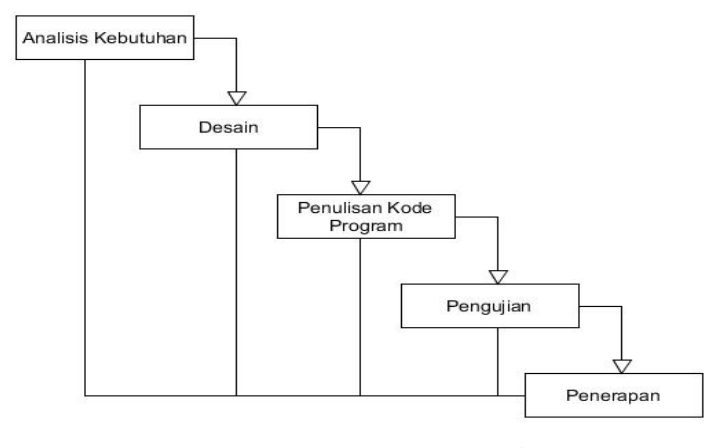

Gambar 1. Metode Penelitian Waterfall [11]

\subsection{Analisis Kebutuhan}

Tahap ini menganalisis kebutuhan dari sistem yang dikembangkan. Analisis kebutuhan yang dilakukan yaitu fungsional dan non-fungsional. Kebutuhan fungsional dari sistem yaitu dapat melakukan pencatatan pemasukan pengeluaran, mencari sekaligus mencetak laporan keuangan, dan manajemen permintaan laporan. Kebutuhan nonfungsional sistem ini dapat dijalankan dengan menggunakan komputer atau laptop pada umumnya. Spesifikasi komputer atau laptop yang digunakan yaitu memiliki RAM 4GB, Memori 1TB untuk penyimpanan data. Software tambahan untuk menjalankan sistem ini yaitu XAMPP dan Web browser Google Chrome.

\subsection{Desain}

Tahap ini membuat desain perancangan sistem yang akan dikembangkan. Beberapa rancangan yang dibuat yaitu usecase, activity diagram, dan ER Diagram.

\subsubsection{Usecase Diagram}

Secara umum usecase digunakan untuk menggambarkan fungsi apa saja yang terdapat pada sebuah sistem dan siapa saja yang dapat menggunakan fungsi-fungsi tersebut [12].

Pada Gambar 2 menggambarkan usecase diagram yang menjelaskan bahwa user dari sistem ini hanya satu pihak yang disebut dengan admin. Admin dapat melakukan pengolahan data pada sistem yang meliputi login ke sistem, mencatat pemasukan, mencatat pengeluaran, menghasilkan laporan keuangan dan mengedit beberapa data. 


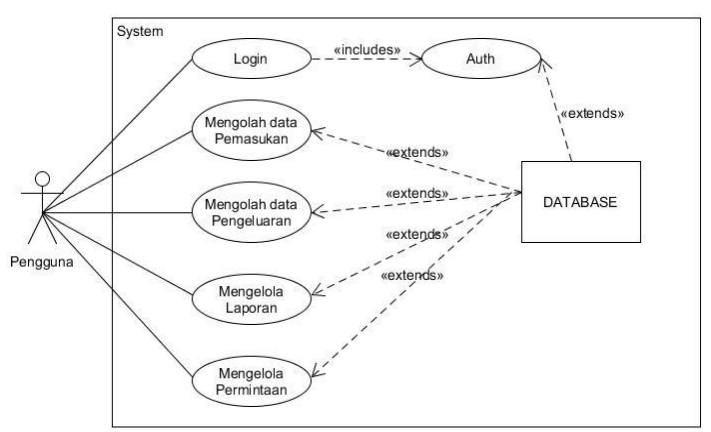

Gambar 2. Usecase Diagram

\subsubsection{Activity Diagram}

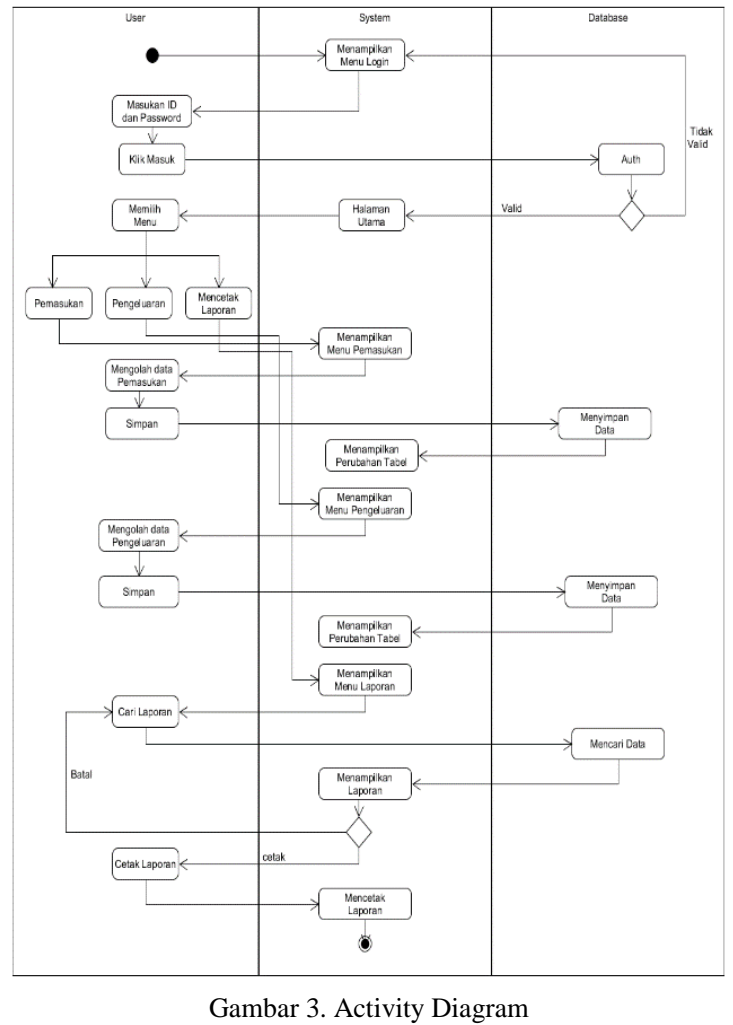

Gambar 3 menampilkan bagaimana alur penggunaan sistem informasi keuangan. Pengguna akan login terlebih dahulu dengan memasukan username dan password. Setelah pengguna sudah masuk sistem maka pengguna dapat memilih menu pencatatan, pemasukan, pengeluaran, dan laporan. Dalam menu pemasukan user melakukan pencatatan uang masuk dan disimpan ke database begitu juga dengan menu pengeluaran. Ketika user masuk kedalam menu laporan maka user dapat melihat laporan dan bisa mencetak laporan sesuai kebutuhan.

\subsubsection{ER Diagram}

ER Diagram menggambarkan bagaimana relasi antar tabel pada sistem yang dibuat. Gambar 4 merupakan gambar dari sebuah ER Diagram.

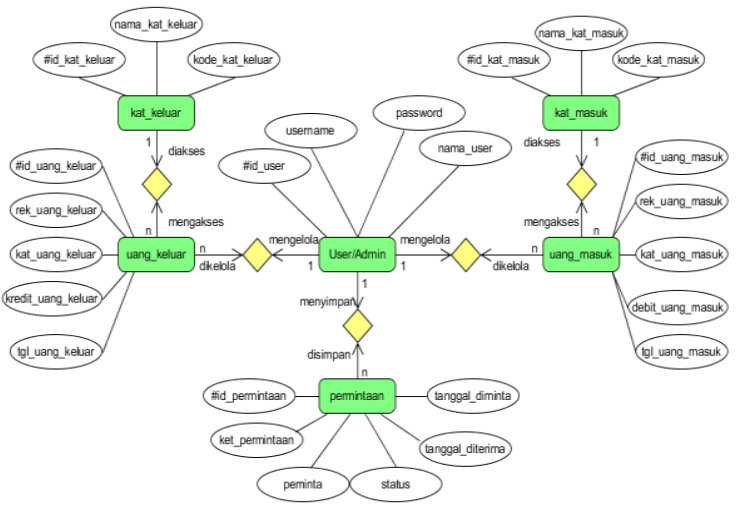

Gambar 4. ER Diagram

Pada Gambar 4 merupakan gambaran dari ER Diagram dari sistem informasi manajemen keuangan Pondok Pesantren Adh-Dhuha yang menggambarkan entitas, atribut, dan relasi. Setiap entitas memiliki atribut sebagai karakteristik dari entitas tersebut, sedangkan relasi merupakan hubungan antar entitas satu dengan yang lainya.

\subsection{Penulisan Kode Program}

Tahapan penulisan kode program ini menggunakan Bahasa pemrograman PHP dan beberapa alat bantu pendukung lainya yaitu XAMPP digunakan sebagai server karena jika menggunakan bahasa pemrograman PHP maka diperlukan XAMPP. Sublime text digunakan sebagai tempat menulis program yang akan digunakan untuk mengembangkan sistem. Tahap ini juga menggunakan framework codeighiter untuk memudahkan developer dalam mengembangkan sistem.

\subsection{Pengujian}

Sistem yang dikembangkan diperlukan pengujian untuk menguji sistem sudah berjalan dengan baik atau belum. Hasil dari pengujian dapat digunakan untuk memprediksi keberhasilan dari sebuah sistem yang baru. Dalam tahap ini menggunakan dua model pengujian yaitu Blackbox dan System Usability Scale (SUS). Pengujian Blackbox ini memiliki fokus masukan untuk aplikasi dan output yang diinginkan dari data yang dimasukan. Pengujian hanya menguji sesuai atau tidak dengan kebutuhan pengguna. [13]. System Usability Scale (SUS) dilakukan dengan membuat kuisioner sebagai sarana dalam melakukan pengujian. SUS bersifat quick dan dirty. Metode pengujian SUS ini menggunakan 10 pertanyaan dengan tanggapan berupa lima poin untuk setiap pertanyaan. Hasil pengujian SUS ini berupa skor antara 0 sampai dengan 100 [14].

\subsection{Penerapan}

Tahapan ini menerapkan sistem di Pondok Pesantren Adh-Dhuha dan melakukan pemantauan 
terhadap sistem. Dilakukan pemantauan sistem untuk mengetahui sudah berjalan dengan baik atau belum sistem tersebut, jika ditemukan masalah maka sistem akan diperbaiki hingga sistem berjalan dengan baik.

\section{HASIL DAN PEMBAHASAN}

Pada hasil dan pembahasan ini membahas hasil yang didapat dan juga pembahasan terkait penelitian.

\subsection{Halaman Tampilan}

Pada Gambar 5 merupakan tampilan dari halaman login. Login merupakan tahap awal dalam menggunakan sistem informasi keuangan ini. Tahap awal penggunaan sistem ini pengguna akan memasukan username dan password untuk dapat masuk kedalam sistem.

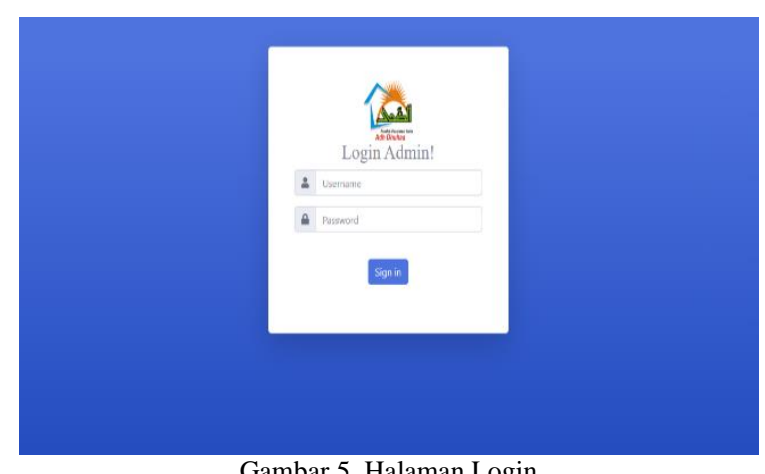

Gambar 5. Halaman Login

Pada Gambar 6 menampilkan halaman dashboard. Halaman dashboard merupakan tampilan awal dari sistem ini yang berisi grafik saldo bulanan selama satu tahun dan juga informasi singkat pemasukan, pengeluaran, saldo, dan jumlah permintaan yang belum direspon.
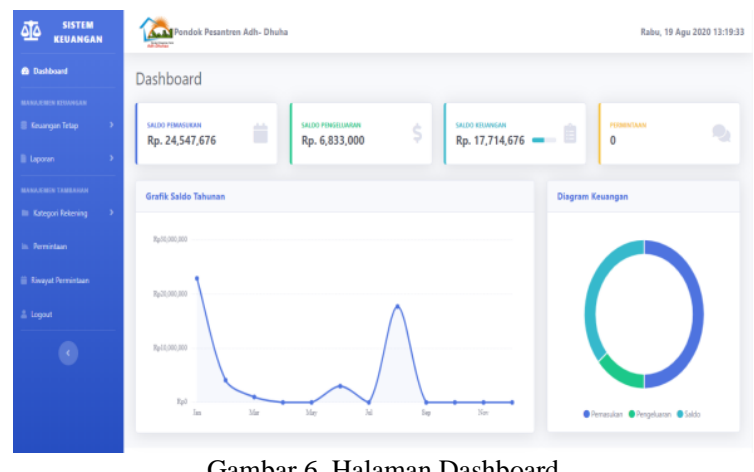

Gambar 6. Halaman Dashboard

Pada Gambar 7 merupakan tampilan dari menu pemasukan. Di menu pemasukan pengguna sistem akan memasukan data pemasukan sesuai dengan uang yang masuk ke instansi tersebut.
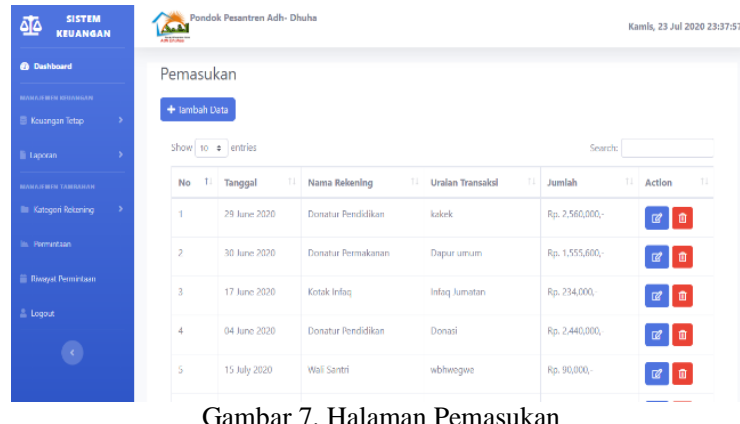

Gambar 7. Halaman Pemasukan

Pada Gambar 8 menampilkan menu pengeluaran yang tidak jauh berbeda dengan menu pemasukan. Pengguna akan memasukan data uang keluar sesuai kebutuhan instansi. Dengan adanya data pemasukan dan pengeluaran maka nantinya dapat menghasilkan sebuah laporan.
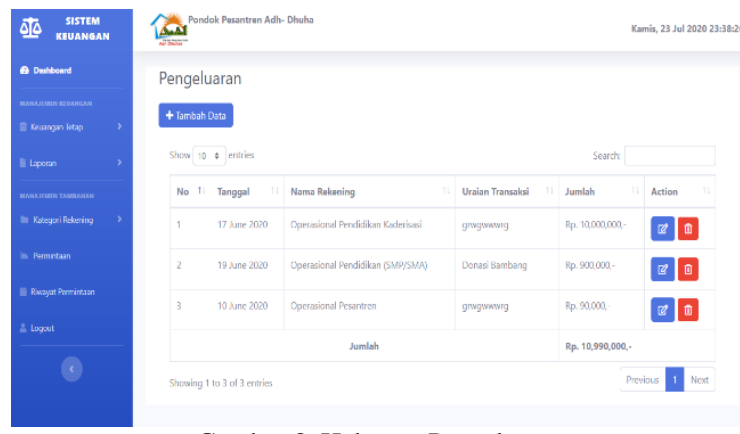

Gambar 8. Halaman Pengeluaran

Pada Gambar 9 menampilkan tampilan dalam mencari laporan berdasarkan bulan dan tahun. Laporan dalam sistem keuangan ini ada dua jenis yaitu laporan keuangan dan laporan kas. Setiap laporan dicetak sesuai bulan dan tahun.

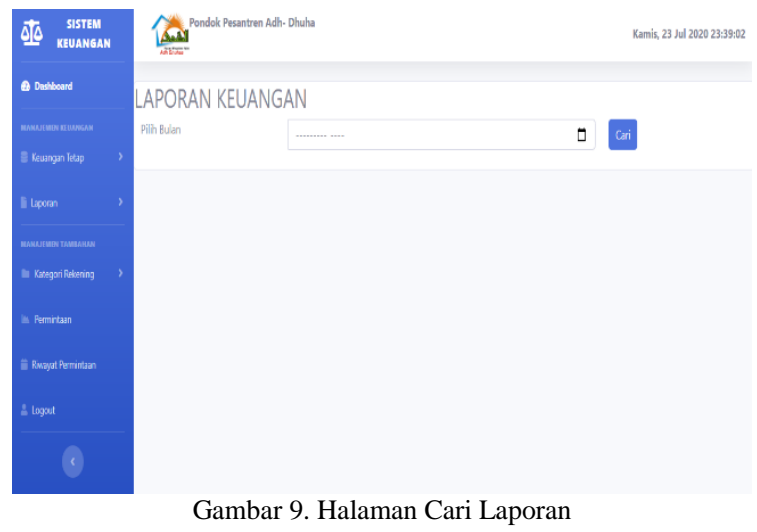

Pada Gambar 10 menampilkan hasil dari pencarian laporan sesuai bulan dan tahun yang dimasukan. Jika laporan ingin dicetak maka dapat print atau simpan dalam bentuk pdf. 

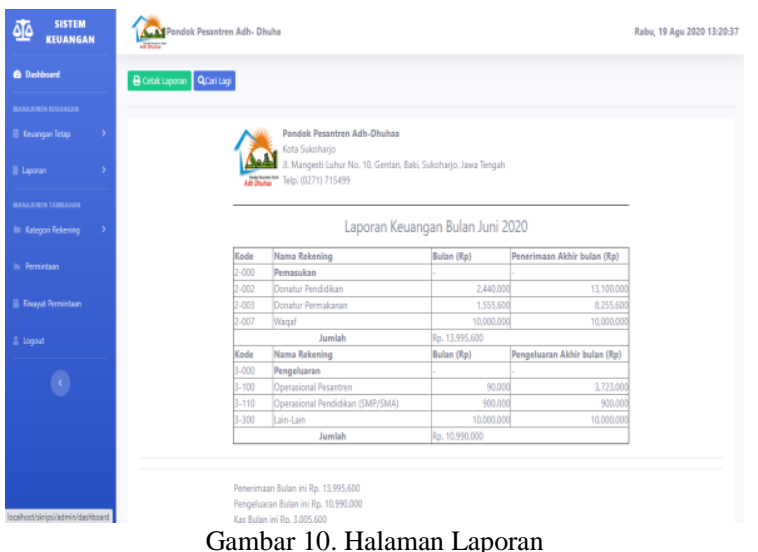

Pada Gambar 11 menampilkan halaman permintaan, pada halaman permintaan ini setiap permintaan dapat dicatat sehingga pengguna dapat menyediakan laporan keuangan yang dibutuhkan secara tepat waktu.
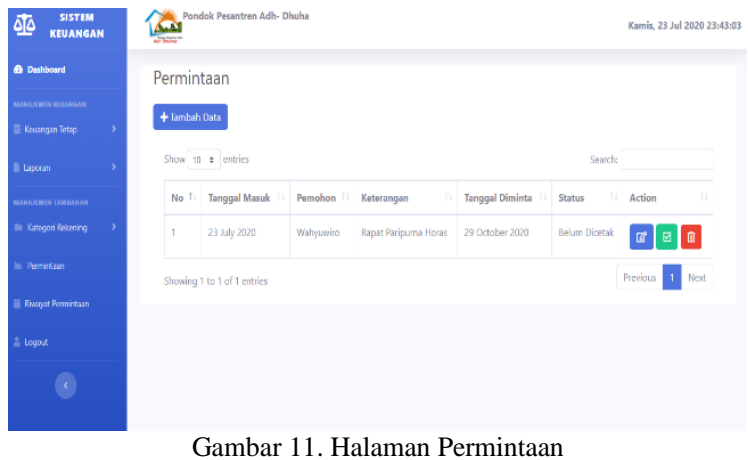

Pada Gambar 12 adalah tampilan halaman riwayat permintaan yang berisi tabel dengan status 'sudah berhasil'. Permintaan yang sudah disetujui atau dicetak akan disimpan sebagai arsip di menu riwayat permintaan. Ketika data sudah tidak dibutuhkan maka pengguna dapat menghapus data tersebut
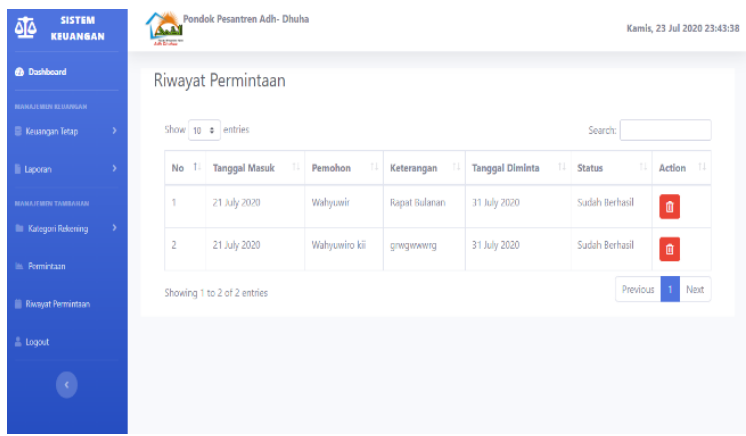

Gambar 12. Halaman Riwayat Permintaan

\subsection{Pengujian Sistem}

\subsubsection{Pengujian Blackbox}

Pengujian sistem informasi keuangan menggunakan Blackbox testing dilakukan untuk mengetahui setiap fitur sudah berhasil dijalankan atau belum.
Tabel 1. Hasil Pengujian Blackbox Testing

\begin{tabular}{|c|c|c|c|}
\hline Usecase & Yang Diuji & $\begin{array}{l}\text { Hasil Yang } \\
\text { Diharapkan }\end{array}$ & Hasil \\
\hline Login & Tombol login & $\begin{array}{c}\text { Dapat masuk ke sistem } \\
\text { sesuai dengan } \\
\text { password dan } \\
\text { username yang } \\
\text { ditentukan }\end{array}$ & Valid \\
\hline \multirow[t]{2}{*}{ Logout } & $\begin{array}{l}\text { Tombol } \\
\text { logout }\end{array}$ & $\begin{array}{c}\text { Menuju ke halaman } \\
\text { login }\end{array}$ & Valid \\
\hline & $\begin{array}{c}\text { Tombol } \\
\text { tambah data }\end{array}$ & $\begin{array}{l}\text { Menuju ke halaman isi } \\
\text { data pemasukan }\end{array}$ & Valid \\
\hline \multirow{3}{*}{$\begin{array}{l}\text { Mengolah } \\
\text { data } \\
\text { pemasukan }\end{array}$} & $\begin{array}{c}\text { Tombol edit } \\
\text { data }\end{array}$ & $\begin{array}{l}\text { Menuju ke halaman } \\
\text { edit data yang dipilih }\end{array}$ & Valid \\
\hline & $\begin{array}{l}\text { Tombol hapus } \\
\text { data }\end{array}$ & $\begin{array}{c}\text { Menghapus data yang } \\
\text { dihapus }\end{array}$ & Valid \\
\hline & $\begin{array}{c}\text { Tombol } \\
\text { tambah data }\end{array}$ & $\begin{array}{l}\text { Menuju ke halaman isi } \\
\text { data pengeluaran }\end{array}$ & Valid \\
\hline \multirow[t]{2}{*}{$\begin{array}{l}\text { Mengolah } \\
\text { data keluar }\end{array}$} & $\begin{array}{l}\text { Tombol edit } \\
\text { data }\end{array}$ & $\begin{array}{l}\text { Menuju ke halaman } \\
\text { edit data yang dipilih }\end{array}$ & Valid \\
\hline & $\begin{array}{l}\text { Tombol hapus } \\
\text { data }\end{array}$ & $\begin{array}{c}\text { Menghapus data yang } \\
\text { dihapus }\end{array}$ & Valid \\
\hline \multirow{3}{*}{$\begin{array}{l}\text { Mengolah } \\
\text { Laporan }\end{array}$} & $\begin{array}{c}\text { Tombol } \\
\text { mencari data } \\
\text { laporan }\end{array}$ & $\begin{array}{c}\text { Menampilkan laporan } \\
\text { berdasarkan bulan } \\
\text { yang dipilih }\end{array}$ & Valid \\
\hline & $\begin{array}{l}\text { Tombol cetak } \\
\text { laporan }\end{array}$ & $\begin{array}{l}\text { Mencetak laporan } \\
\text { sesuai pencarian }\end{array}$ & Valid \\
\hline & $\begin{array}{c}\text { Tombol } \\
\text { tambah data }\end{array}$ & $\begin{array}{l}\text { Menuju ke halaman isi } \\
\text { data pemasukan }\end{array}$ & Valid \\
\hline \multirow[t]{3}{*}{$\begin{array}{l}\text { Mengolah } \\
\text { permintaan }\end{array}$} & $\begin{array}{c}\text { Tombol edit } \\
\text { data }\end{array}$ & $\begin{array}{l}\text { Menuju ke halaman } \\
\text { edit data yang dipilih }\end{array}$ & Valid \\
\hline & $\begin{array}{l}\text { Tombol hapus } \\
\text { data }\end{array}$ & $\begin{array}{c}\text { Menghapus data yang } \\
\text { dihapus }\end{array}$ & Valid \\
\hline & $\begin{array}{l}\text { Tombol } \\
\text { verifikasi } \\
\text { permintaan } \\
\text { laporan }\end{array}$ & $\begin{array}{c}\text { Memindahkan data ke } \\
\text { menu riwayat cetak } \\
\text { laporan dengan status } \\
\text { berhasil }\end{array}$ & Valid \\
\hline
\end{tabular}

Pengujian yang dilakukan pertama yaitu Login karena sebelum masuk ke sistem pengguna harus memasukan username dan password yang sudah ditentukan. Pengujian berikutnya adalah menguji semua tombol yang ada didalam sistem informasi keuangan. Hasil dari pengujian ini menunjukan sistem dapat berjalan dengan baik dan sesuai harapan. Bukti dari pengujian Blackbox testing ditampilkan pada tabel 1 .

\subsubsection{Pengujian System Usability Scale (SUS)}

Pengujian System Usability Scale (SUS) terdiri dari 10 pertanyaan. Responden dari SUS akan menilai kegunaan dari sistem pada skala 5-point nomor dari 1 (sangat tidak setuju) sampai 5(sangat setuju). Setiap pertanyaan memiliki skor kontribusi antara 0 sampai 4. Untuk pertanyaan nomor ganjil skor kontribusinya yaitu nilai dari pertanyaan dikurangi 1 sedangkan untuk nomor genap skor kontribusinya yaitu 5 dikurangi nilai pertanyaan. Sebuah sistem dianggap baik jika skor SUS keseluruhan diatas 68 [15].

Pada gambar 13 menunjukan rentang penilaian yang memiliki tiga klasifikasi yaitu acceptability ranges, grade scale, dan adjective rating. 


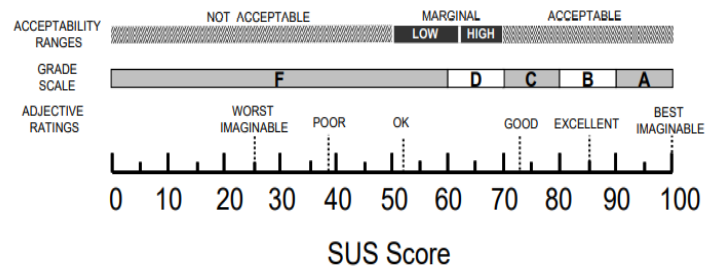

Gambar 13. Penilaian System Usability Scale [16]
Pada tabel 2 menunjukan hasil dari perhitungan dari pengujian system usability testing (SUS). Ratarata nilai yang didapat pada penilaian system usability testing yaitu 74,25. Mengacu pada gambar 13 maka dengan nilai tersebut dapat disimpulkan bahwa sistem dinilai baik dan dapat digunakan untuk memenuhi kebutuhan instansi dalam melakukan manajemen keuangan baik.

Tabel 2. Hasil pengujian system usability scale (SUS)

\begin{tabular}{|c|c|c|c|c|c|c|c|c|c|c|c|c|}
\hline \multirow[t]{2}{*}{ Responden } & \multicolumn{10}{|c|}{ Pertanyaan } & \multirow[t]{2}{*}{ Jumlah } & \multirow[t]{2}{*}{ Nilai } \\
\hline & $\mathrm{P} 1$ & $\mathrm{P} 2$ & P3 & $\mathrm{P} 4$ & P5 & P6 & $\mathrm{P} 7$ & P8 & $\mathrm{P9}$ & $\mathrm{P} 10$ & & \\
\hline 1 & 2 & 4 & 4 & 3 & 3 & 3 & 3 & 3 & 4 & 3 & 32 & 80 \\
\hline 2 & 3 & 4 & 4 & 4 & 3 & 2 & 3 & 4 & 3 & 1 & 31 & 77,5 \\
\hline 3 & 4 & 4 & 3 & 4 & 3 & 3 & 3 & 4 & 3 & 3 & 34 & 85 \\
\hline 4 & 2 & 3 & 3 & 2 & 3 & 3 & 2 & 3 & 4 & 2 & 27 & 67,5 \\
\hline 5 & 3 & 4 & 4 & 3 & 3 & 2 & 3 & 4 & 3 & 1 & 30 & 75 \\
\hline 6 & 4 & 3 & 4 & 2 & 4 & 3 & 3 & 2 & 4 & 2 & 31 & 77,5 \\
\hline 7 & 4 & 2 & 3 & 2 & 3 & 2 & 3 & 3 & 4 & 3 & 28 & 70 \\
\hline 8 & 3 & 3 & 3 & 2 & 3 & 3 & 3 & 4 & 4 & 1 & 29 & 72,5 \\
\hline 9 & 3 & 3 & 3 & 1 & 3 & 3 & 3 & 3 & 3 & 1 & 26 & 65 \\
\hline 10 & 4 & 2 & 3 & 2 & 4 & 2 & 3 & 3 & 4 & 2 & 29 & 72,5 \\
\hline \multicolumn{12}{|c|}{ Rata-rata } & 74,25 \\
\hline
\end{tabular}

\section{KESIMPULAN}

Pengembangan sistem yang dilakukan menghasilkan sistem informasi manajemen keuangan yang dapat mengelola data keuangan masuk dan keluar, serta mengelola laporan keuangan dengan baik. Berdasarkan pengujian menggunakan blackbox testing diketahui bahwa setiap menu pada sistem dapat berjalan sesuai dengan fungsinya dan semua tombol $100 \%$ dapat berfungsi dengan baik. Pengujian system usability testing mendapatkan nilai rata-rata 74,25 maka disimpulkan bahwa sistem yang dibuat dapat digunakan dengan baik.

\section{DAFTAR PUSTAKA}

[1] S. Shofia and D. A. Anggoro, "Sistem Informasi Manajemen Administrasi dan Keuangan pada TK-IT Permata Hati Sumberrejo-Bojonegoro," J. Ilmu Pengetah. Dan Teknol. Komput., vol. 5, no. 2, pp. 221230, 2020.

[2] L. Hardiyanti, K. Haris, D. Putu, Y. Ardiana, I. P. Agus, and E. Darma, "Rancang Bangun Sistem Informasi Akuntansi di STIKI Copy Center," J. Sist. Inf. dan Komput. Terap. Indones., vol. 2, no. 2, pp. 77-88, 2019.

[3] H. Widiastuti and A. Fatmawati, "Sistem Informasi Produksi Usaha Mikro Kecil Menengah Pada Zahroh Barokah," J. INSYPRO (Information Syst. Process., vol. 4, no. 2, pp. 1-7, 2019.

[4] M. Nurkamid, S. Mulyani, and B. Gunawan, "Development of Accounting Information System for Small and Medium Enterprises ( SME ) Batik Bakaran Juwana Pati Central
Java,” no. 4, pp. 187-197, 2018.

[5] H. Setiyawati and C. M. Doktoralina, "The importance of quality accounting information management in regional governments in Indonesia," Manag. Sci. Lett., vol. 9, no. 12, pp. 2083-2092, 2019.

[6] C. L. Permatasari, S. Dian, and Prajanti, "Acceptance of Financial Accounting Information System at Schools : Technology Acceptance Model," J. Econ. Educ., vol. 7, no. 52, pp. 109-120, 2018.

[7] A. Syukron, B. S. Informatika, B. S. Informatika, A. Keuangan, and P. Asuhan, "Sistem Informasi Manajemen Administrasi Keuangan Panti Asuhan Berbasis Website," J. Responsif, vol. 2, no. 2, pp. 150-157, 2020.

[8] R. Meilano and H. K. Sumitra, "Accounting information system of saving and loan Cooperative at PT . Pelabuhan Indonesia II Jambi ( Persero )," J. Appl. Account. Bus., vol. 1, no. 1, 2019.

[9] N. Hidayati, "Pengembangan Sistem Informasi Pengeluaran Kas Atas Pengadaan Proyek Dengan Menggunakan Metode Waterfall," J. Komput. dan Inform. Univ. Bina Sarana Inform., vol. XXI, no. 1, pp. 6168, 2019.

[10] W. Andriani, D. Ni, and A. Y. Candra, "Design of Accounting Reporting Information Systems of Chicken Farms," EasyChair Prepr., 2019.

[11] H. S. Modi, N. K. Singh, and H. P. Chauhan, "Comprehensive Analysis of Software 
Development Life Cycle Models," Int. Res. J. Eng. Technol., vol. 4, no. 6, pp. 117-122, 2017.

[12] D. Andriansyah, "Penerapan Model Waterfall Pada Sistem Informasi Layanan Jasa Laundry Berbasis Web," Indones. J. Softw. Eng., vol. 4, no. 1, pp. 27-32, 2018.

[13] A. Verma, A. Khatana, and S. Chaudhary, “A Comparative Study of Black Box Testing and White Box Testing," Int. J. Comput. Sci. Eng., vol. 5, no. 12, pp. 301-304, 2017.

[14] W. W. W. Kharis, Paulus Insap Santosa, "Evaluasi Usability Pada Sistem Informasi Pasar Kerja Menggunakan System Usability Scale (SUS)," pp. 240-245, 2017.

[15] Z. Sharfina, H. B. Santoso, and A. Usability, "An Indonesian Adaptation of the System Usability Scale ( SUS )," ICACSIS, vol. 16, 2016.

[16] A. Bangor, T. Staff, P. Kortum, J. Miller, and T. Staff, "Determining What Individual SUS Scores Mean: Adding an Adjective Rating Scale," J. Usability Stud., vol. 4, no. 3, pp. 114-123, 2009. 